\title{
Consumer Buying Behaviour and Brand Loyalty in Rural Markets: FMCG
}

\author{
B.V.N.G. ChandraSekhar \\ Academic and Internship Programme Indian Institute of Management Baanagalore Bannerghatta Road, \\ Bangalore, India
}

\begin{abstract}
Prime Minister Manmohan Singh recently talked about his vision for rural India: "My vision of rural India is of a modern agrarian, industrial and services economy co-existing side by side, where people can live in wellequipped villages and commute easily to work, be it on the farm or in the non-farm economy. There is much that modern science and technology can do to realize this vision. Rural incomes have to be increased. Rural infrastructure has to be improved. Rural health and education needs have to be met. Employment opportunities have to be created in rural areas." 'Go rural' is the slogan of marketing gurus after analyzing the socio-economic changes in villages. The Rural population is nearly three times the urban, so that Rural consumers have become the prime target market for consumer durable and non-durable products, food, construction, electrical, electronics, automobiles, banks, insurance companies and other sectors besides hundred per cent of agri-input products such as seeds, fertilizers, pesticides and farm machinery. The Indian rural market today accounts for only about Rs. 8 billion of the total ad pie of Rs 120 billion, thus claiming 6.6 per cent of the total share. So clearly, there seems to be a long way ahead. Although a lot is spoken about the immense potential of the unexplored rural market, advertisers and companies find it easier to vie for a share of the already divided urban pie.The success of a brand in the Indian rural market is as unpredictable as rain. It has always been difficult to gauge the rural market. Many brands, which should have been successful, have failed miserably. More often than not, people attribute rural market success to luck. Therefore, marketers need to understand the social dynamics and attitude variations within each village. Though, nationally it follows a consistent pattern looking at the challenges and the opportunities which rural markets offer to the marketers it can be said that the future is very promising for those who can understand the dynamics of rural markets and exploit them to their best advantage. A radical change in attitudes of marketers towards the vibrant and burgeoning rural markets is called for, so they can successfully impress on the 230 million rural consumers spread over approximately six hundred thousand villages in rural India.The Indian established Industries have the advantages, which MNC do not enjoy in this regard. The strong Indian brands have strong brand equity, consumer demand-pull and efficient and dedicated dealer network which have been created over a period of time. The brand has to be made relevant by understanding local needs. Even offering the same product in different regions with different brand names could be adopted as a strategy. At times, it is difficult to pass on an innovation over an existing product to the rural consumer unlike his urban counterpart - like increased calcium or herbal content or a germ-control formula in toothpaste.The rural market has a grip of strong country shops, which affect the sale of various products in rural market. The companies are trying to trigger growth in rural areas. They are identifying the fact that rural people are now in the better position with disposable income. The low rate finance availability has also increased the affordability of purchasing the costly products by the rural people. Marketer should understand the price sensitivity of a consumer in a rural area. This paper is therefore an attempt to promote the brand image in the rural market
\end{abstract}

Keywords: Rural Markets, Consumer Behavior, Brand, Brand Loyalty, Rural Customers, Local Brand

\section{Introduction}

Indian Marketers on rural marketing have two understanding (i) The urban metro products and marketing products can be implemented in rural markets with some or no change. (ii) The rural marketing required the separate skills and techniques from its urban counter part. The Marketers have following facilities to make them believe in accepting the truth that rural markets are different in so many terms.

(i) The rural market has the opportunity for many brands.

(ii) Low priced products can be more successful in rural markets because the low purchasing, purchasing powers in rural markets.

(iii) Rural consumers have mostly homogeneous group with similar needs, economic conditions and problems. (iv) The rural markets can be worked with the different media environment as opposed to press, film, radio and other urban centric media exposure.

How reality does affect the planning of marketers? Do villagers have same attitude like urban consumers? The question arises for the management of rural marketing effects in a significant manner so than companies can enter in the rural market with the definite goals and targets but not for a short term period but for longer 
duration. The Research paper will discuss the role of regard. The strategy, which will be presented in the paper, can be either specific or universally applicable.

Realities before the Marketers:

$70 \%$ of India's population lives in 627000 villages in rural areas. $90 \%$ of the rural population we concentrated in villages with a population of less than 2000, with agriculture being the main business. This simply shows the great potentiality rural India has to bring the much - needed volume- driven growth. This brings a boon in disguise for the FMCG Company who has already reached the plateau of their business urban India. As per the National Council for Applied Economic Research (NCAER) study, there are as many 'middle income and above' households in the rural areas as there are in the urban areas. There are almost twice as many' lower middle income' households in rural areas as in the urban areas. At the highest income level, there are 2.3 million urban households as against 1.6 million households in rural areas. According to the NCAER projections, the number of middle and high-income households in rural India is expected to grow from 80 million to 111 million by 2007. In urban India, the same is expected to grow from 46 million to 59 million. Thus, the absolute size India is expected to be doubles that of urban India.

HLL chairman MS Banga Says, "This exercise may not pay in the immediate future, but will definitely give long-term dividends. Incidentally, over 50 percent of the sales of HLL's fabric wash, personal wash and beverages are in rural areas. And we see a future in going rural in a major way".

The improved agricultural growth is expected to boost rural demand, through not at too sizzling a rate. Moreover, the price drop in personal products, after the recent excise duty reductions, in also expected to drive consumption. "Better agricultural yields will give farmers more spending power, making the rural markets bullish," says an analyst.

As a result, HLL has planned a rural marketing program that is expected to result in a marked growth in the consumption of the company's products in the rural market. HLL will adopt three-pronged marketing strategy- new price points, sizes and awareness campaigns for its detergents and soaps segment to augment rural growth. The Indian established Industries have the advantages, which MNC do not enjoy in this regard. The strong Indian brands have strong brand equity, consumer demand-pull and efficient and dedicated dealer network which have been created over a period of time. The rural market has a grip of strong country shops, which affect the sale of various products in rural market.

The companies are trying to trigger growth in rural areas. They are identifying the fact that rural people are now in the better position with disposable income. The low rate finance availability has also increased the affordability of purchasing the costly products by the rural people. Marketer should understand the price sensitivity of a consumer in a rural area. The small sachet packs are the examples of price sensitivity. Colgate has done this experiment with launching of sachet packs for rural markets.

Within the broad framework of marketing, consumer behavior is the most interesting area and one concerned with understanding why an individual consumer acts in certain consumption related ways. The complexity of behavior, however, varies with the nature of the product and need. While buying a product to satisfy an individual need do the Brand plays an important role or not, In this regard a study has conducted in rural areas to know the importance of Brand in consumer buying behavior of FMCG goods.

\section{Objectives of the study}

1.1.1 To study on brand loyalty of various brands in rural markets

1.1.2 To study does the brand play a role in the purchase behavior of rural customers

1.1.3 To study on which categories/products does brand play a role

1.1.4 To identify the presence and the importance of local brands

\section{Scope of the study}

A lot of work has been done on various aspects of rural marketing. Hence, it was felt necessary to make a humble attempt to study the importance of Brand in consumer Buying Behavior of FMCG goods in rural markets.

\section{Description Methodology}

To study the importance of Brand consumer Buying Behavior of FMCG goods in rural areas, the primary data was collected with the help of a structured questionnaire. First, with an adhoc questionnaire, a study was conducted on a sample of 60 respondents in the village's satanapalli, tadipattri and mallapur, while, redrafting the questionnaire some questions were added, modifications were made, and the final questionnaire was prepared. The survey was conducted in the village's chintulla; Akulamylaram, Badangpeta and nadergul, selection of these villages were made based on first study. While doing the survey with the adhoc questionnaire we found that there is huge difference in the consumer buying behavior this may of different reasons like nonavailability of brands, brand awareness, influence, etc. Keeping these things in mind the survey was conducted in three different areas. 
The Importance of Brand in Consumer Buying Behavior of FMCG goods in Rural Markets

1.3.1 To study the urban influence on consumer buying behavior, the village that is closer to urban.

1.3.2 A village where there will be an availability of different brands.

1.3.3 Remote Area where awareness and availability of brands are less

\subsection{Research Design}

The research design used was exploratory and descriptive research design, because was made on convenient random sample.

\subsection{Questionnaire}

The questionnaire was prepared keeping in view the objectives of study. Different questions were so arranged that field information is collected from the consumer awareness on brand of different FMCG products, Brand Loyalty, preferences of brand/brands, local brands, and frequency of usage.

Questionnaire contains two types of questions

1.5.1 Open Ended

Open Ended Questions are used for exploratory study.

Closed ended questions used for descriptive study.

\subsection{Sample Design}

Telangana is one of the three regions of Andhra Pradesh consisting of 10 districts, except Hyderabad; capital city of the state, the entire Telangana region is a backward and more rural in character. This region represents the average Indian rural characteristics in terms of sizes of rural population, agricultural economy, small size village, low density population, low literacy rate, low per capita income and consequent lower standard of living of the people. The ten districts of the region, Ranga Reddy district has selected for the study as the district has much covered with the capital city and it is surround the capital city we thought this is the best area to do survey to meet the objectives of the project.

\subsection{Field Study}

1.7.1 The Source of Data: The study is based on Primary as well as secondary data. The primary data was collected with the help of structured questionnaire. The survey was conducted in the rural areas of TelanganaBadangpet, Nadergul, and Chintulla.

1.7.2 Determination of sample: The size of sample was 30 from each of the village that constitute 90 respondents in total from all 3 villages.

\begin{tabular}{|l|l|l|l|}
\hline Soap Category & Badangpet & Nadergul & Chintulla \\
\hline Lux & 20 & 10 & 5 \\
\hline NO.1 & 17 & 0 & 0 \\
\hline Santoor & 30 & 10 & 25 \\
\hline Margo & 15 & 0 & 0 \\
\hline Medimix & 22 & 0 & 10 \\
\hline Cinthol & 25 & 0 & 0 \\
\hline Rexona & 30 & 7 & 3 \\
\hline Margo & 10 & 0 & 0 \\
\hline Mysore & 10 & 0 & 0 \\
\hline Palmolive & 1 & 0 & 0 \\
\hline Life bouy & 0 & 25 & 30 \\
\hline Liril & 0 & 3 & 0 \\
\hline Hamam & 0 & 15 & 0 \\
\hline Life bouy Plus & 0 & 5 & 0 \\
\hline Breeze & 0 & 0 & 0 \\
\hline
\end{tabular}

1.7.3 Collection of Data: The primary data was collected through a questionnaire. 
Brand Awareness in Rural Areas

\section{Research Data:}

Table 1: Brand awareness of soaps in villages and number of Respondents are 30.

\section{Graph 1:}

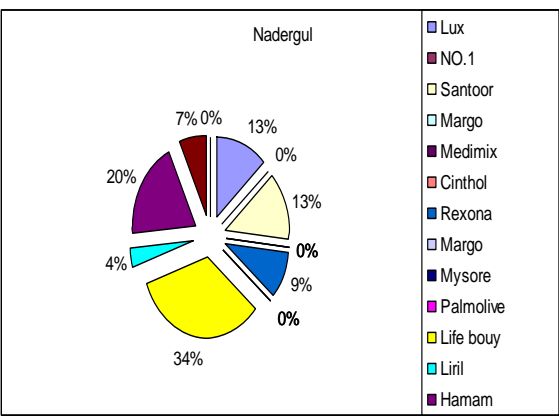

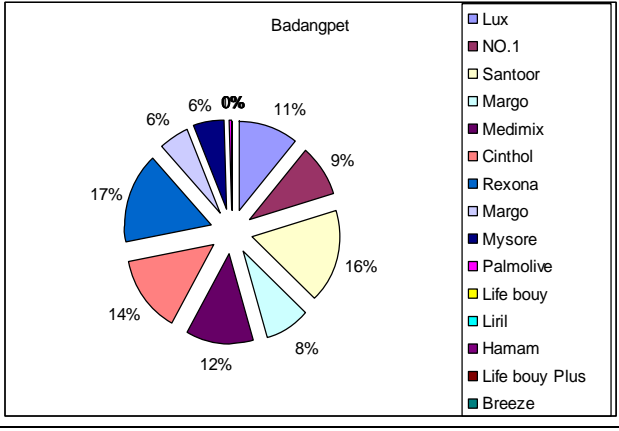

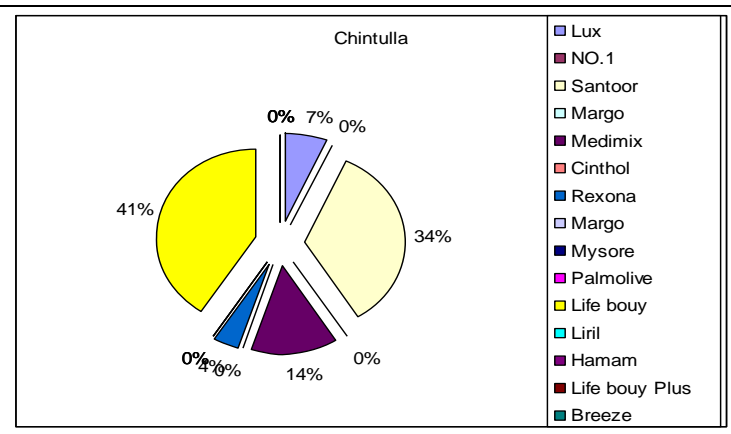

It is very clear, from the above table and Pie Chart that the brand awareness in Badangpet is more when compared to Nadergul and Chintula.

Table 2: Brand awareness of Hair Oil in villages and number of Respondents are 30.

\begin{tabular}{|l|l|l|l|}
\hline Hair Oil Category & Badangpet & Nadergul & Chintulla \\
\hline Navratan & 17 & 0 & 0 \\
\hline Aswini & 15 & 3 & 3 \\
\hline Clinic Plus & 5 & 0 & 0 \\
\hline Vatika & 10 & 5 & 0 \\
\hline Parachute & 30 & 10 & 2 \\
\hline Coco Care & 5 & 0 & 0 \\
\hline KeoKarpin & 6 & 0 & 0 \\
\hline Almon drops & 5 & 0 & 0 \\
\hline Brylcream & 1 & 0 & 0 \\
\hline Amul(Local Brand) & 0 & 1 & 0 \\
\hline Gograda & 0 & 1 & 1 \\
\hline Dabur & 0 & 0 & 0 \\
\hline
\end{tabular}

Graph 2:

\begin{tabular}{lll|}
\hline & Badangpet
\end{tabular}




Chintulla \begin{tabular}{l}
\hline Navatan \\
$\square$ Aswini \\
$\square$ Clinic Plus \\
$\square$ Vatika \\
$\square$ Parachute \\
$\square$ Coco Care \\
$\square$ KeoKarpin \\
$\square$ Almon drops \\
B Brylcream \\
a Amul(Local Brand) \\
$\square$ Gograda \\
$\square$ Dabur
\end{tabular}

It is very clear, from the above table and Pie Chart that the brand awareness in Badangpet is more when compared to Nadergul and Chintula.

Table 3: Brand awareness of Biscuits in village and number of Respondents are 30.

\begin{tabular}{|l|l|l|l|}
\hline Biscuits Category & Badangpet & Nadergul & Chintulla \\
\hline Krack Jack & 10 & 10 & 0 \\
\hline Parle-g & 20 & 10 & 5 \\
\hline Tiger & 15 & 10 & 0 \\
\hline Marie & 10 & 0 & 0 \\
\hline Britannia & 2 & 0 & 0 \\
\hline Cadbury's & 1 & 0 & 0 \\
\hline Good Day & 1 & 0 & 0 \\
\hline Glucose & 0 & 5 & 0 \\
\hline 50-50 & 10 & 5 & 0 \\
\hline Ampro & 0 & 1 & 0 \\
\hline Rose Salt & 0 & 1 & 0 \\
\hline
\end{tabular}

\section{Graph 3:}

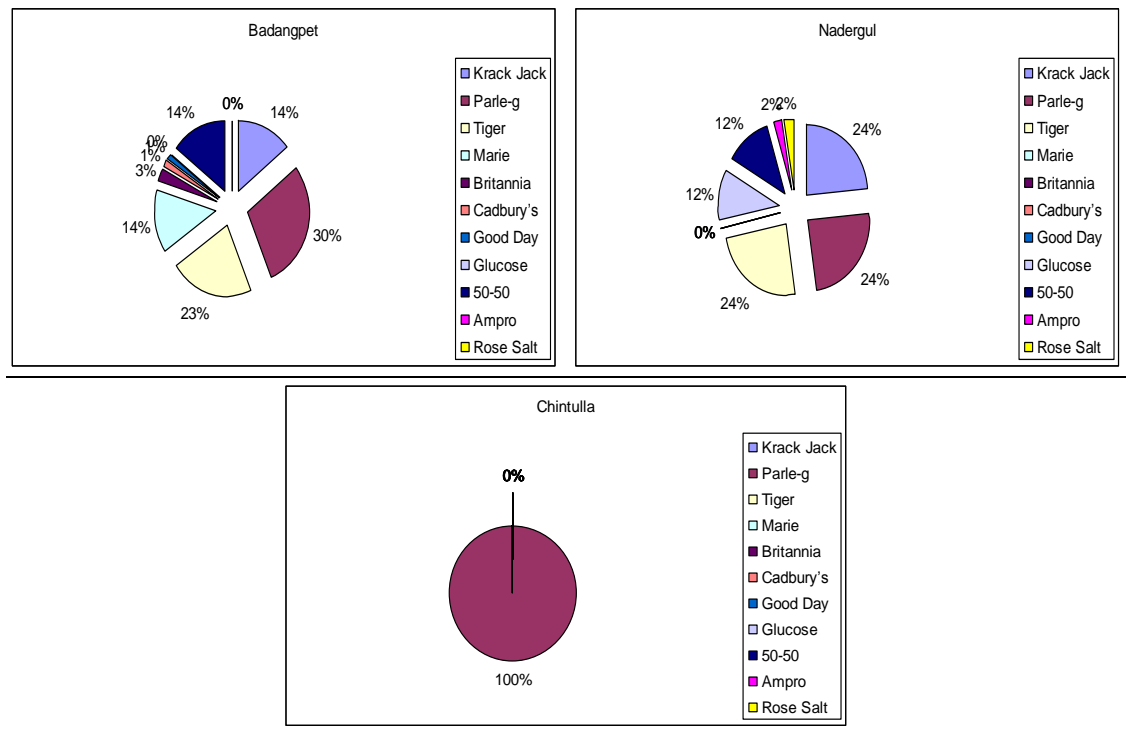

It is very clear, from the above table and Pie Chart that the brand awareness in Badangpet is more when compared to Nadergul and Chintula.

Table 4: Brand awareness of Tea in village and number of Respondents are 30.

\begin{tabular}{|l|l|l|l|}
\hline Tea Category & Badengpet & Nadergul & Chintulla \\
\hline Three Roses & 25 & 10 & 10 \\
\hline Red label & 22 & 0 & 0 \\
\hline Chakra Gold & 12 & 5 & 0 \\
\hline AVT Assam & 2 & 0 & 0 \\
\hline Tata & 4 & 0 & 0 \\
\hline Gemini & 20 & 2 & 2 \\
\hline
\end{tabular}




\begin{tabular}{|l|l|l|l|} 
Tajmahal & 15 & 10 & 0 \\
\hline Lamsa & 0 & 1 & 0 \\
\hline Royal Tea & 0 & 0 & 15 \\
\hline
\end{tabular}

\section{Graph 4:}

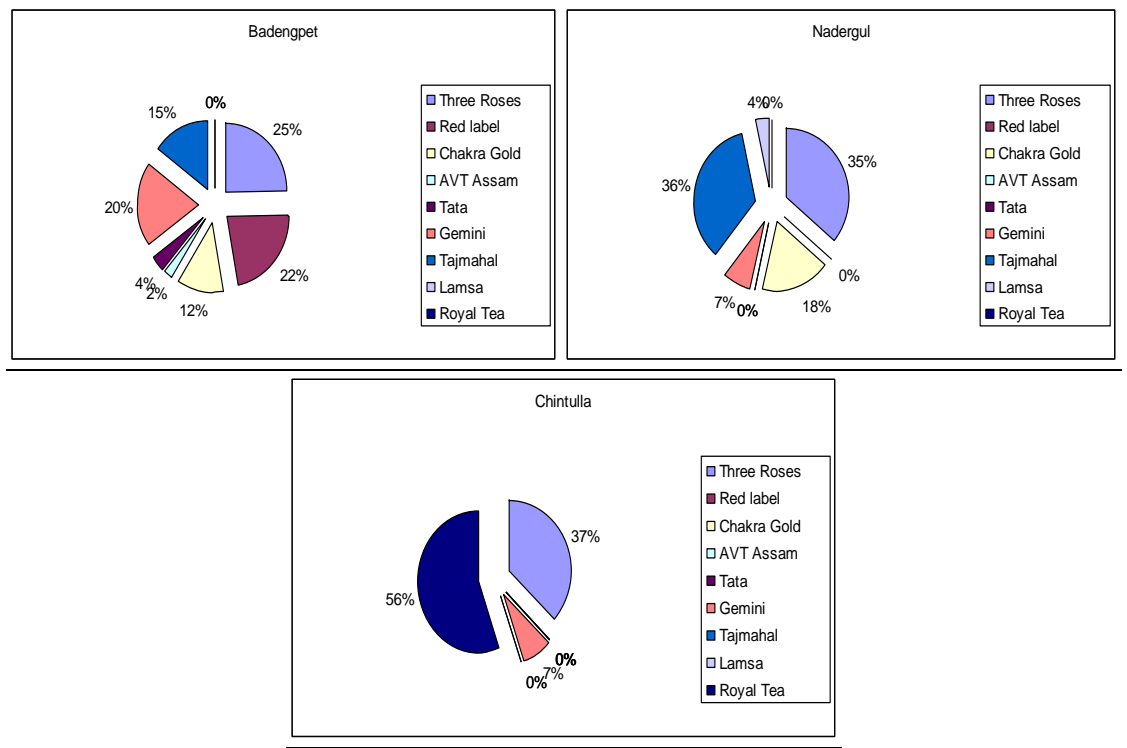

It is very clear, from the above table and Pie Chart that the brand awareness in Badangpet is more when compared to Nadergul and Chintula.

Table 5: Brand awareness of Coffee in village and number of Respondents are 30.

\begin{tabular}{|l|l|l|l|}
\hline Coffee Category & Badengpet & Nadergul & Chintulla \\
\hline Bru & 10 & 10 & 0 \\
\hline Green Label & 12 & 0 & 0 \\
\hline Nescafe & 5 & 0 & 0 \\
\hline
\end{tabular}

\section{Graph 5:}

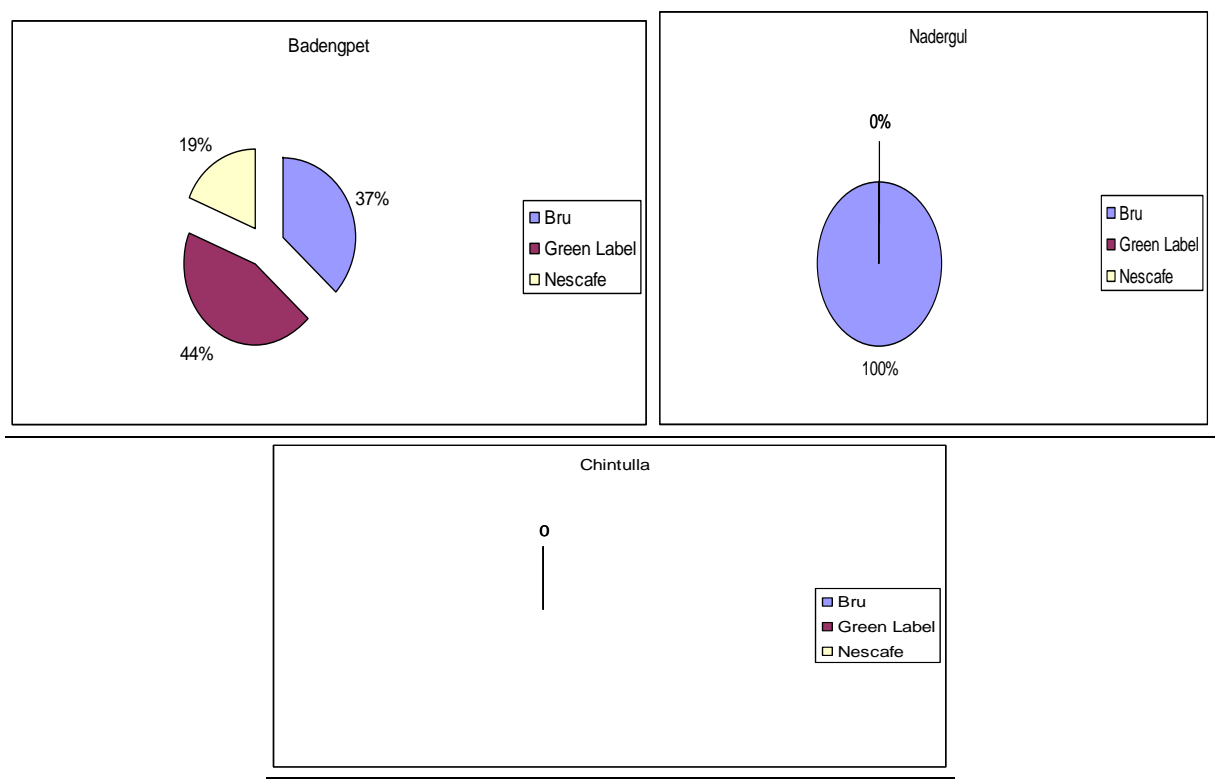

It is very clear, from the above table and Pie Chart that the brand awareness in Badangpet is more when compared to Nadergul and Chintula. Consumption of coffee is very low or no consumption in Chintulla. 
The Importance of Brand in Consumer Buying Behavior of FMCG goods in Rural Markets

Table 6: Brand awareness of Washing Powder in Badangpet village and number of Respondents are 30.

\begin{tabular}{|l|l|l|l|}
\hline Washing Powder & Badengpet & Nadergul & Chintulla \\
\hline Ariel & 25 & 3 & 0 \\
\hline SurfExcel & 30 & 2 & 0 \\
\hline Tide & 20 & 10 & 0 \\
\hline Rin & 15 & 15 & 0 \\
\hline Wheel & 30 & 15 & 0 \\
\hline Nirma & 30 & 25 & 20 \\
\hline Rin Shakti & 0 & 10 & 0 \\
\hline
\end{tabular}

\section{Graph 6:}

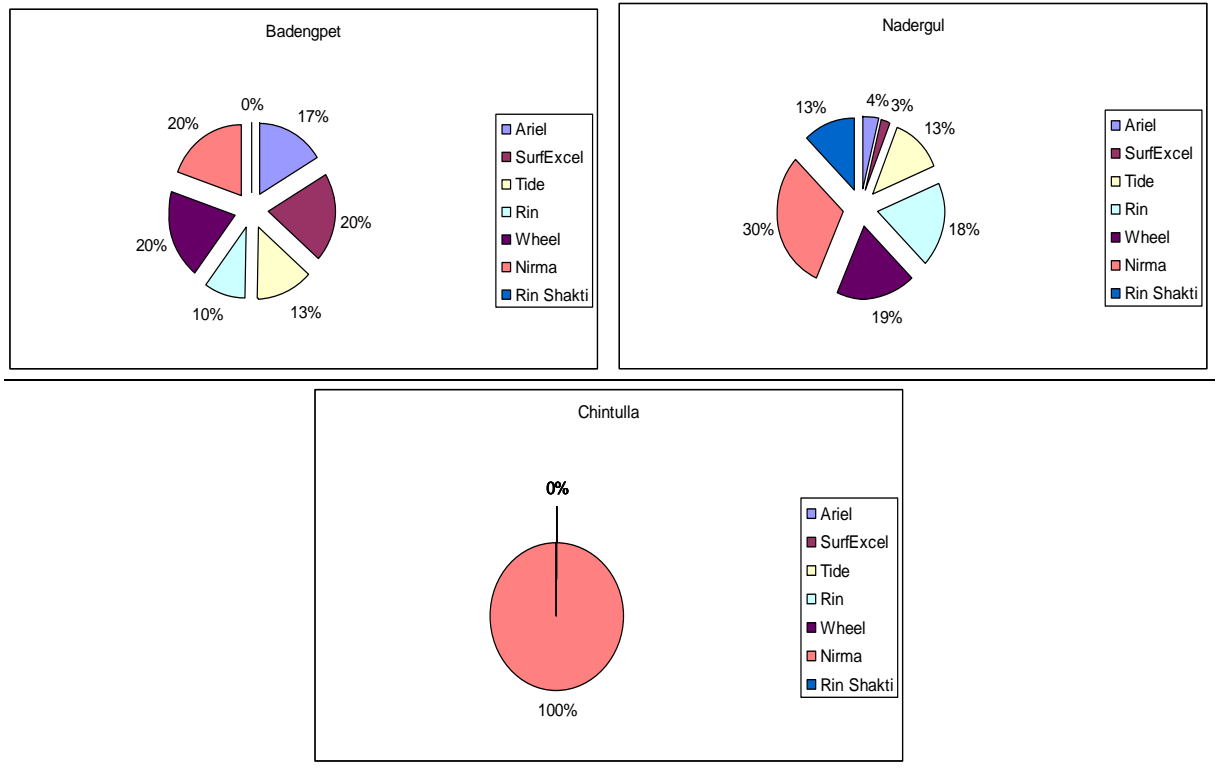

It is very clear, from the above table and Pie Chart that the brand awareness in Badangpet is more when compared to Nadergul and Chintula.

Table 7: Brand awareness of Washing Soap in village and number of Respondents are 30.

\begin{tabular}{|l|l|l|l|}
\hline Washing Soap & Badengpet & Nadergul & Chintulla \\
\hline Rin & 30 & 30 & 5 \\
\hline Wheel & 20 & 0 & 0 \\
\hline Soap 501 & 25 & 30 & 20 \\
\hline Rin Supreme & 30 & 0 & 0 \\
\hline Extra & 0 & 25 & 0 \\
\hline Nirma & 0 & 30 & 30 \\
\hline XXX & 0 & 20 & 25 \\
\hline ETA & 0 & 20 & 20 \\
\hline
\end{tabular}

\section{Graph 7:}

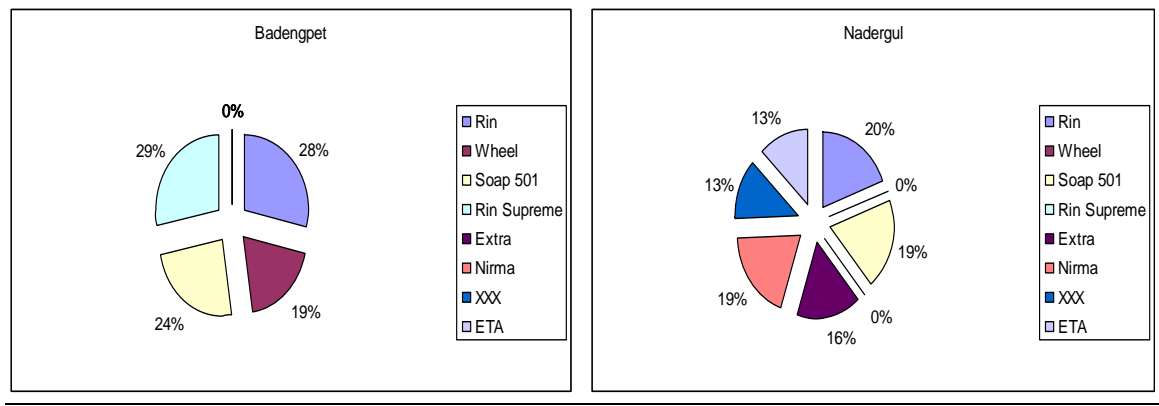




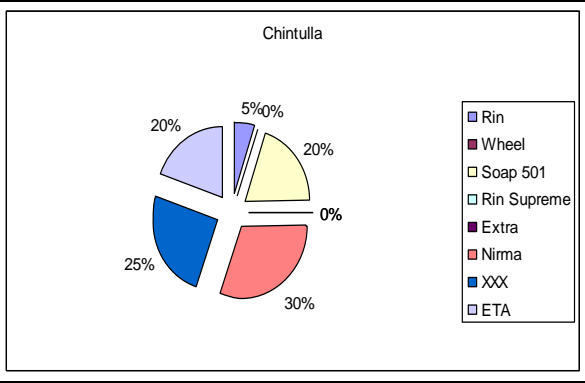

It is very clear, from the above table and Pie Chart that the brand awareness in Badangpet is more when compared to Nadergul and Chintula.

Table 8: Brand awareness of Face Powder in village and number of Respondents are 30.

\begin{tabular}{|l|l|l|l|}
\hline Face Powder & Badengpet & Nadergul & Chintulla \\
\hline Ponds & 20 & 25 & 20 \\
\hline Fa & 1 & 0 & 0 \\
\hline Axe & 1 & 0 & 0 \\
\hline Park avenue & 1 & 0 & 0 \\
\hline Sprint & 2 & 0 & 0 \\
\hline Shower to Shower & 1 & 0 & 0 \\
\hline Boro plus & 5 & 0 & 0 \\
\hline Emami & 5 & 0 & 0 \\
\hline Ashoka & 10 & 10 & 0 \\
\hline Chintol & 20 & 0 & 10 \\
\hline Santoor & 15 & 20 & 15 \\
\hline Spinz & 0 & 1 & 0 \\
\hline
\end{tabular}

\section{Graph 8:}
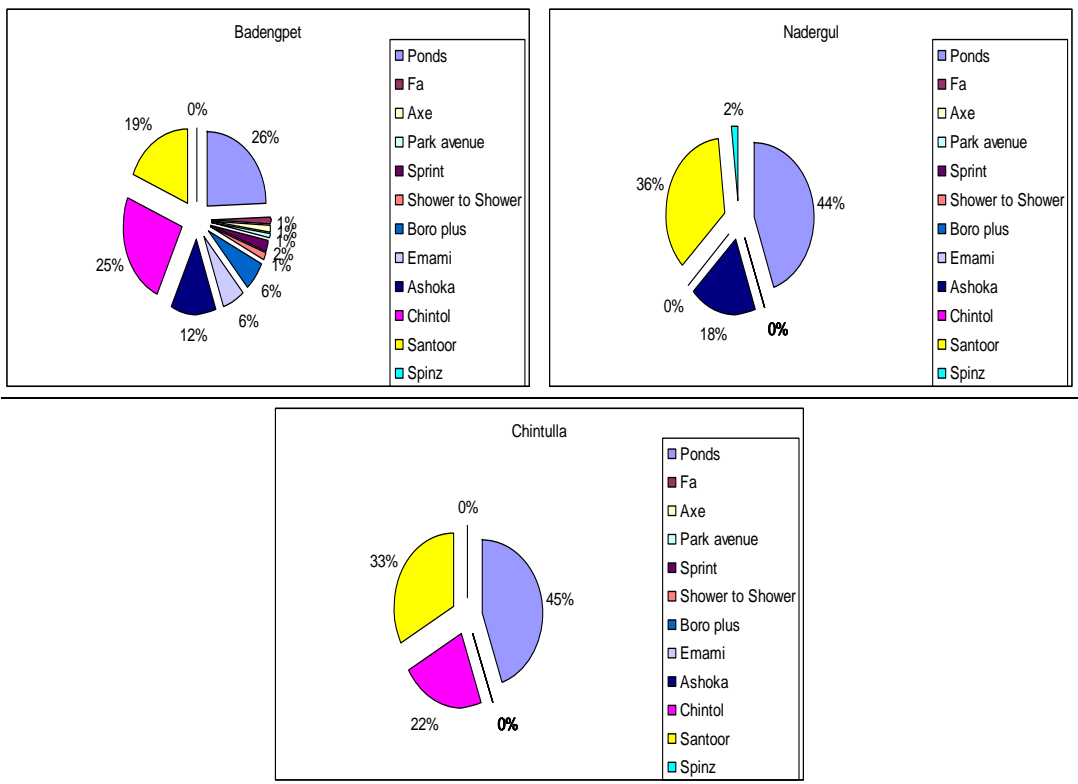

It is very clear, from the above table and Pie Chart that the brand awareness in Badangpet is more when compared to Nadergul and Chintula.

Table 9: Brand awareness of Cold Cream in villages and number of Respondents are 30.

\begin{tabular}{|l|l|l|l|}
\hline Cold Cream & Badengpet & Nadergul & Chintulla \\
\hline Ponds & 25 & 5 & 0 \\
\hline Kashmir Snow & 2 & 2 & 0 \\
\hline Vaseline & 10 & 0 & 0 \\
\hline
\end{tabular}


Graph 9:

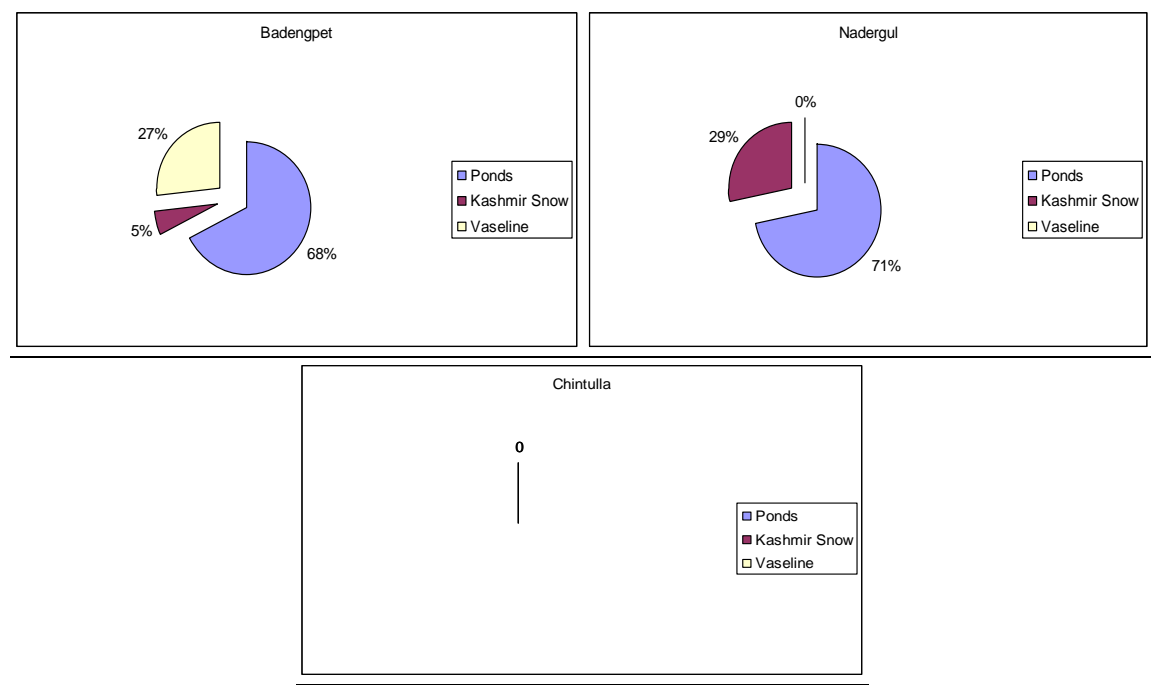

It is very clear, from the above table and Pie Chart that the brand awareness in Badangpet is more when compared to Nadergul and Chintula

Table 10: Brand awareness of Fairness Cream in village and number of Respondents are 30.

\begin{tabular}{|l|l|l|l|}
\hline Fairness Cream & Badengpet & Nadergul & Chintulla \\
\hline Fair \& Lovely & 25 & 25 & 0 \\
\hline Fair ever & 10 & 5 & 0 \\
\hline
\end{tabular}

\section{Graph 10}

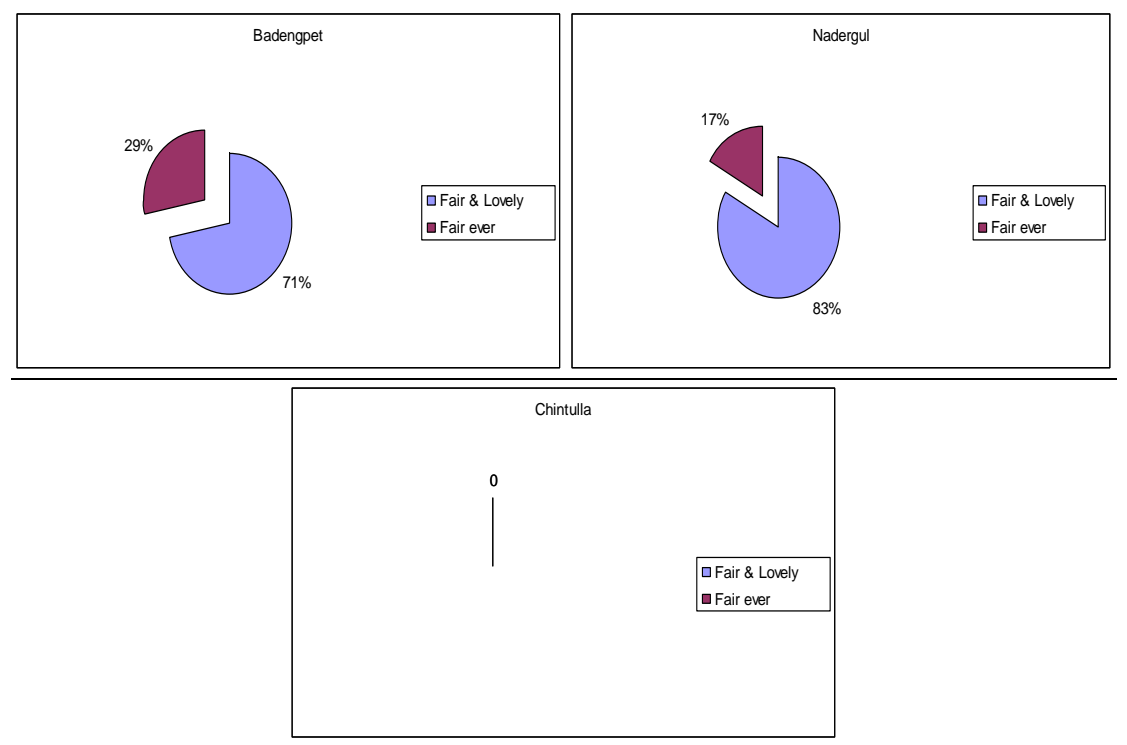

It is very clear, from the above table and Pie Chart that the brand awareness in Badangpet is more when compared to Nadergul and Chintula.

\section{Brands Purchased in Rural Area}

Table 11: Brand Purchased In soap category in villages and number of Respondents are 30.

\begin{tabular}{|l|l|l|l|}
\hline Products & Badangpet & Nadergul & Chintulla \\
\hline Lux & 25 & 10 & 0 \\
\hline NO.1 & 10 & 0 & 1 \\
\hline Santoor & 20 & 10 & 10 \\
\hline
\end{tabular}




\begin{tabular}{|l|l|l|l|} 
Margo & 0 & 0 & 0 \\
\hline Medimix & 0 & 2 & 5 \\
\hline Cinthol & 15 & 5 & 0 \\
\hline Rexona & 0 & 15 & 2 \\
\hline Margo & 0 & 0 & 0 \\
\hline Mysore & 7 & 0 & 0 \\
\hline Palmolive & 1 & 0 & 0 \\
\hline Life bouy & 0 & 20 & 25 \\
\hline Liril & 0 & 1 & 0 \\
\hline Hamam & 0 & 1 & 0 \\
\hline $\begin{array}{l}\text { Life bouy } \\
\text { Plus }\end{array}$ & 0 & 1 & 0 \\
\hline Breeze & 0 & 1 & 0 \\
\hline
\end{tabular}

\section{Graph 11:}

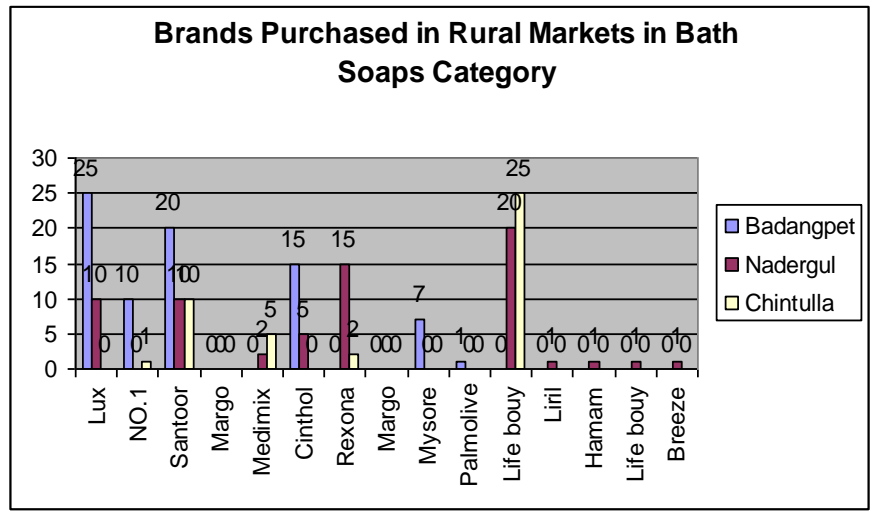

It is very clear, from the above table, graph that the brand purchased in Badangpet is dominated by Lux, Santoor, and Chintol, in Nadergul Lifebouy, Rexona, Santoor and Lux and in Chintula Lifebouy dominates the market.

Table 12: Brand Purchased in Hair Oil category in villages and number of Respondents are 30.

\begin{tabular}{|l|l|l|l|}
\hline Hair Oil & Badangpet & Nadergul & Chintulla \\
\hline Navratan & 10 & 0 & 5 \\
\hline Aswini & 3 & 5 & 0 \\
\hline Clinic Plus & 1 & 0 & 0 \\
\hline Vatika & 15 & 4 & 0 \\
\hline Parachute & 0 & 15 & 2 \\
\hline Coco Care & 0 & 0 & 0 \\
\hline KeoKarpin & 1 & 0 & 0 \\
\hline Almon drops & 0 & 0 & 0 \\
\hline Brylcream & 1 & 0 & 0 \\
\hline Amul(Local) & 0 & 0 & 0 \\
\hline Gograda & 0 & 0 & 3 \\
\hline Dabur & 0 & 0 & 1 \\
\hline Ghar & 0 & 0 & 0 \\
\hline
\end{tabular}




\section{Graph 12:}

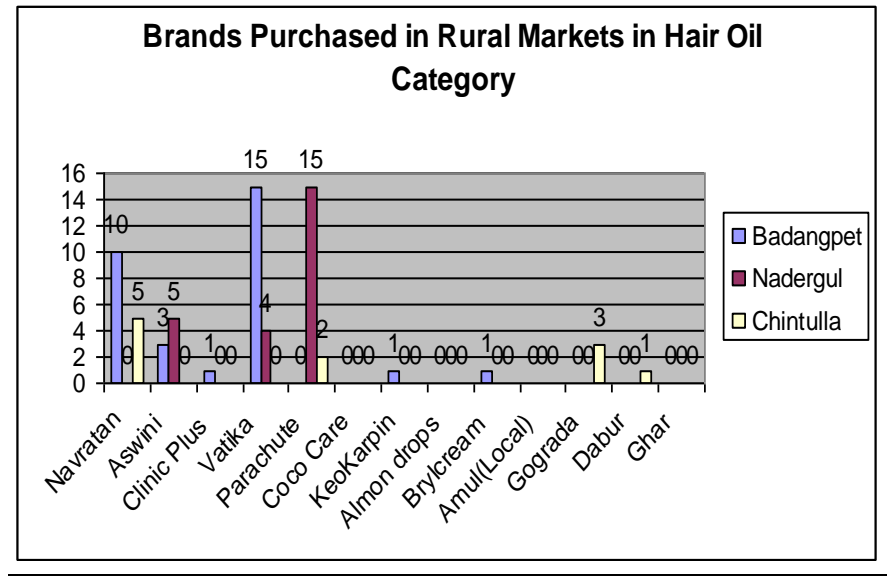

It is very clear, from the above table and graph that the brand purchased in Badangpet Navrathan hair oil dominates the market, Parachute dominates Nadergul markets and Chintula very less consumption of branded hair oils

Table 13: Brand Purchased In Biscuits category in villages and number of Respondents are 30.

\begin{tabular}{|l|l|l|l|}
\hline Biscuits Category & Badangpet & Nadergul & Chintulla \\
\hline Krack Jack & 0 & 5 & 0 \\
\hline Parle-g & 20 & 10 & 1 \\
\hline Tiger & 10 & 5 & 0 \\
\hline Marie & 2 & 0 & 0 \\
\hline Britannia & 0 & 0 & 0 \\
\hline Cadbury's & 0 & 0 & 0 \\
\hline Good Day & 1 & 0 & 0 \\
\hline Glucose & 0 & 1 & 0 \\
\hline $50-50$ & 7 & 2 & 0 \\
\hline Ampro & 0 & 1 & 0 \\
\hline Rose Salt & 0 & 1 & 0 \\
\hline
\end{tabular}

\section{Graph 13:}

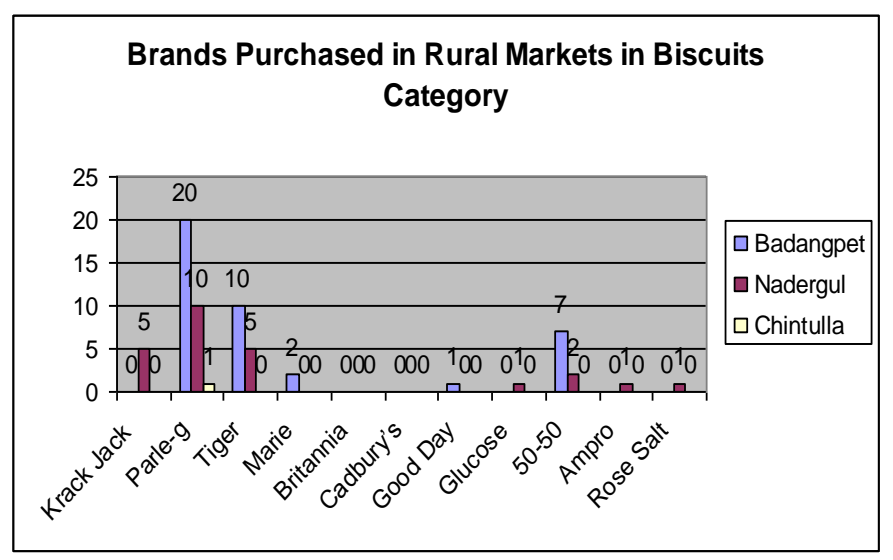

It is very clear, from the above table and graph that the brand purchased in Badangpet is dominated by Parle-g and Tiger Biscuits. In Nadergul and Chintula very less or no consumption of biscuits and market is dominated by local salt or Osmania Biscuits than branded. 
The Importance of Brand in Consumer Buying Behavior of FMCG goods in Rural Markets

Table 14: Brand Purchased in Tea category in villages and number of Respondents are 30.

\begin{tabular}{|l|l|l|l|}
\hline Tea Category & Badangpet & Nadergul & Chintulla \\
\hline Three Roses & 5 & 2 & 2 \\
\hline Red label & 10 & 10 & 5 \\
\hline Chakra Gold & 3 & 0 & 0 \\
\hline AVT Assam & 1 & 0 & 0 \\
\hline Tata & 7 & 0 & 0 \\
\hline Gemini & 15 & 5 & 0 \\
\hline Tajmahal & 3 & 5 & 0 \\
\hline Lamsa & 0 & 1 & 0 \\
\hline Royal Tea(Local) & 0 & 0 & 10 \\
\hline
\end{tabular}

\section{Graph 14:}

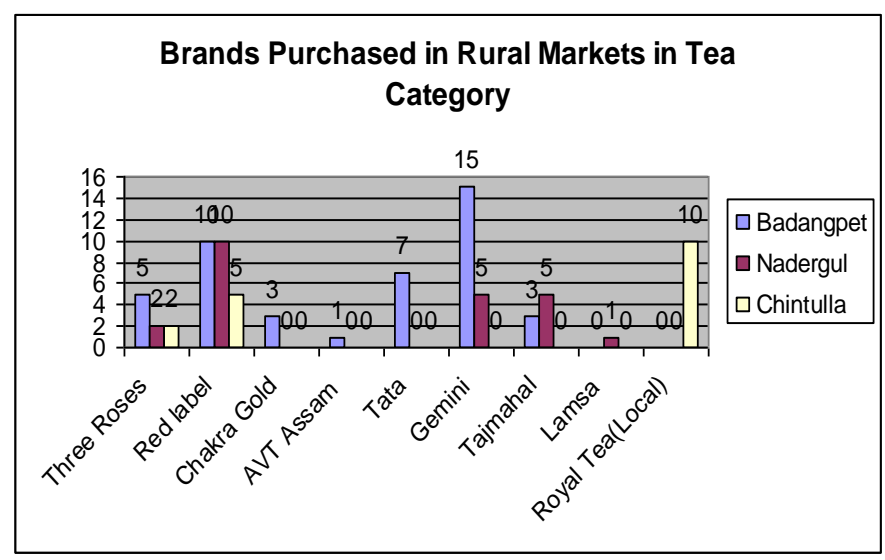

It is very clear, from the above table and graph, the brand purchased in Badangpet is dominated by Gemini and Red label. Red label also dominated the Nadergul market and Chintula market is dominated by local brand Royal Tea.

Table 15: Brand Purchased in Coffee category in villages and number of Respondents are 30.

\begin{tabular}{|l|l|l|l|}
\hline Coffee Category & Badangpet & Nadergul & Chintulla \\
\hline Bru & 10 & 0 & 0 \\
\hline Green Label & 0 & 0 & 0 \\
\hline Nescafe & 0 & 0 & 0 \\
\hline
\end{tabular}

\section{Graph 15:}

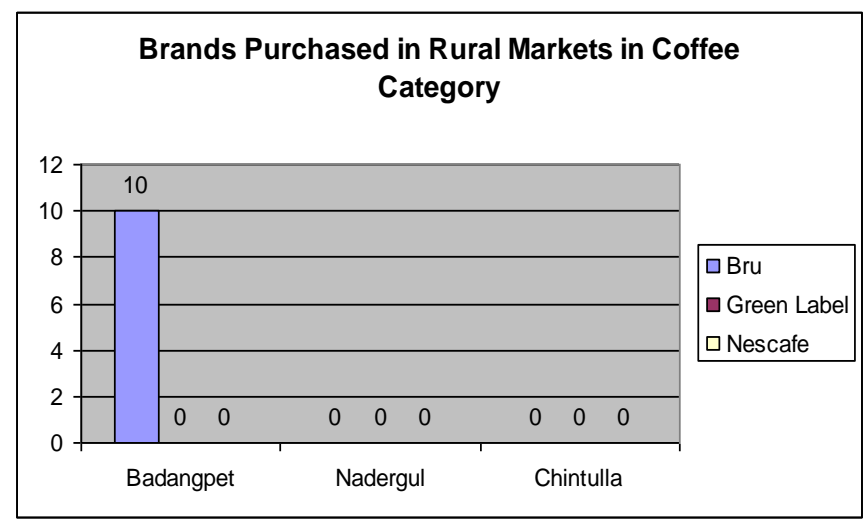

It is very clear, from the above table and graph, the Badangpet market is dominated by Bru Coffee. In Nadergul and Chintula coffee consumption is very low or no consumption. 
The Importance of Brand in Consumer Buying Behavior of FMCG goods in Rural Markets

Table 16: Brand Purchased in Washing Powder category in villages and number of Respondents are 30.

\begin{tabular}{|l|l|l|l|}
\hline Washing Powder & Badengpet & Nadergul & Chintulla \\
\hline Ariel & 5 & 1 & 0 \\
\hline SurfExcel & 7 & 2 & 0 \\
\hline Tide & 3 & 1 & 0 \\
\hline Rin & 15 & 3 & 0 \\
\hline Wheel & 30 & 5 & 0 \\
\hline Nirma & 30 & 20 & 20 \\
\hline Rin Shakti & 0 & 3 & 0 \\
\hline
\end{tabular}

\section{Graph 16:}

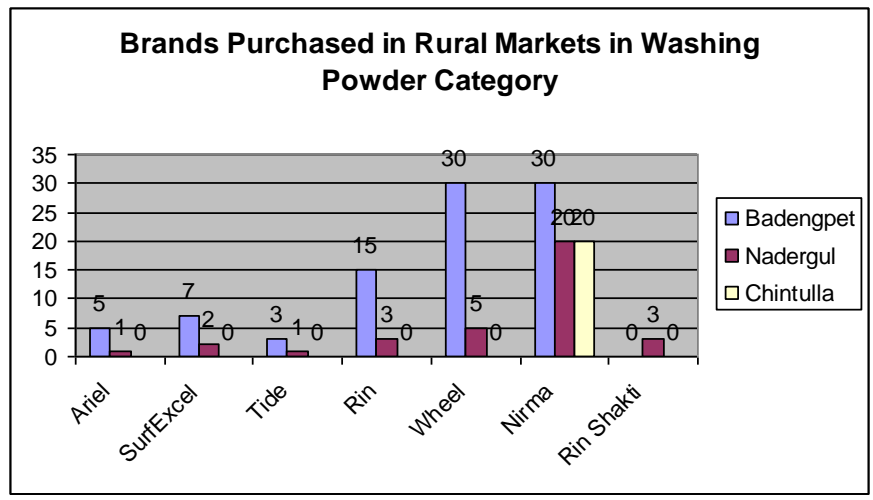

It is very clear, from the above table and graph that Nirma dominates all the three sample villages i.e. Badangpet, Nadergul and Chintula.

Table 17: Brand Purchased in Washing Soap category in villages and number of Respondents are 30.

\begin{tabular}{|l|l|l|l|}
\hline Washing Soap & Badengpet & Nadergul & Chintulla \\
\hline Rin & 30 & 0 & 0 \\
\hline Wheel & 10 & 0 & 0 \\
\hline Soap 501 & 12 & 10 & 15 \\
\hline Rin Supreme & 5 & 0 & 0 \\
\hline Extra & 0 & 5 & 10 \\
\hline Nirma & 0 & 20 & 5 \\
\hline XXX & 0 & 10 & 10 \\
\hline ETA & 0 & 5 & 5 \\
\hline
\end{tabular}

\section{Graph 17:}

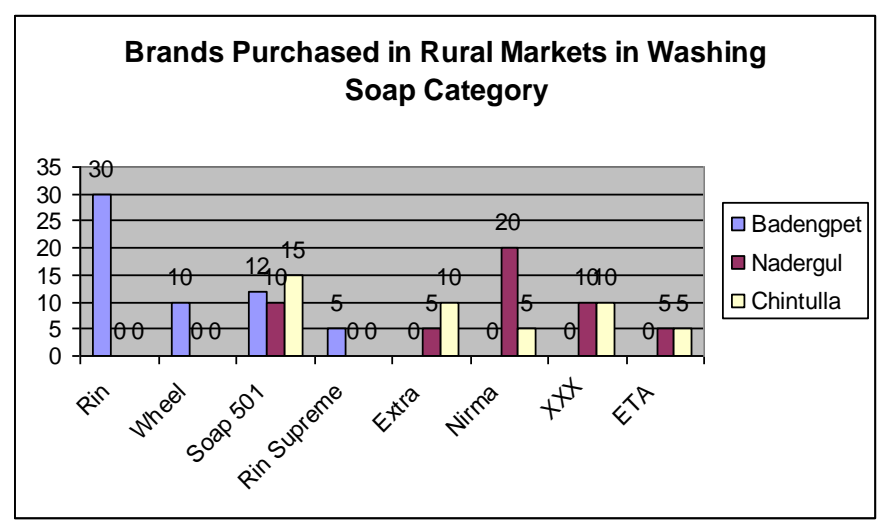

It is very clear, from the above table and graphs that Rin, 501 and Nirma dominates the selected sample rural market. 
The Importance of Brand in Consumer Buying Behavior of FMCG goods in Rural Markets

Table 18: Brand Purchased in Face Powder category in villages and number of Respondents are 30.

\begin{tabular}{|l|l|l|l|}
\hline Face Powder & Badangpet & Nadergul & Chintulla \\
\hline Ponds & 25 & 20 & 20 \\
\hline Fa & 1 & 0 & 0 \\
\hline Axe & 1 & 0 & 0 \\
\hline Park avenue & 1 & 0 & 0 \\
\hline Sprint & 2 & 0 & 0 \\
\hline Shower to Shower & 1 & 0 & 0 \\
\hline Boro plus & 5 & 0 & 0 \\
\hline Emami & 5 & 0 & 0 \\
\hline Ashoka & 3 & 3 & 0 \\
\hline Chintol & 10 & 15 & 10 \\
\hline Santoor & 5 & 10 & 10 \\
\hline Spinz & 0 & 10 & 0 \\
\hline
\end{tabular}

\section{Graph 18:}

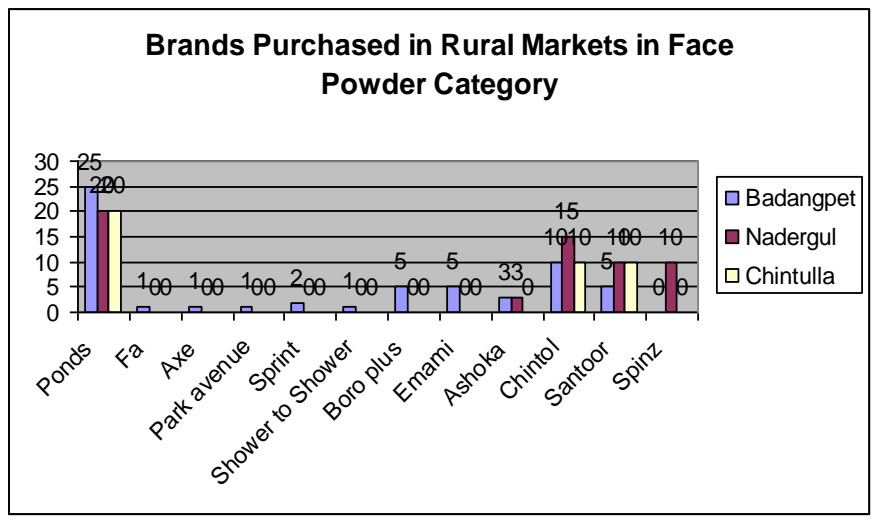

It is very clear, from the above table and graph, that Ponds dominates the Face Powder category in all the three selected rural markets.

Table 19: Brand Purchased in Cold Cream category in villages and number of Respondents are 30.

\begin{tabular}{|c|c|c|c|}
\hline Cold Cream & Badangpet & Nadergul & Chintulla \\
\hline Ponds & 25 & 5 & 0 \\
\hline Kashmir Snow & 2 & 0 & 0 \\
\hline Vaseline & 10 & 0 & 0 \\
\hline
\end{tabular}

\section{Graph 19:}

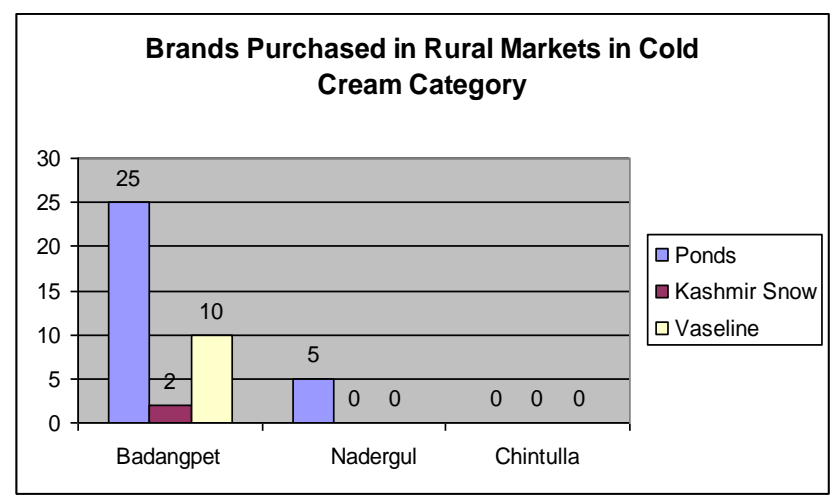

It is very clear, from the above table and graph that Ponds dominates Cold Cream Category in Badangpet. As the consumption pattern is very low or no consumption Ponds also dominates Nadergul and as per survey no brand has tapped the Chintula market 
The Importance of Brand in Consumer Buying Behavior of FMCG goods in Rural Markets

Table 20: Brand Purchased in Fairness Cream category in villages and number of Respondents are 30.

\begin{tabular}{|l|l|l|l|}
\hline Fairness Cream & Badangpet & Nadergul & Chintulla \\
\hline Fair \& Lovely & 25 & 25 & 0 \\
\hline Fair ever & 10 & 5 & 0 \\
\hline
\end{tabular}

\section{Graph 20}

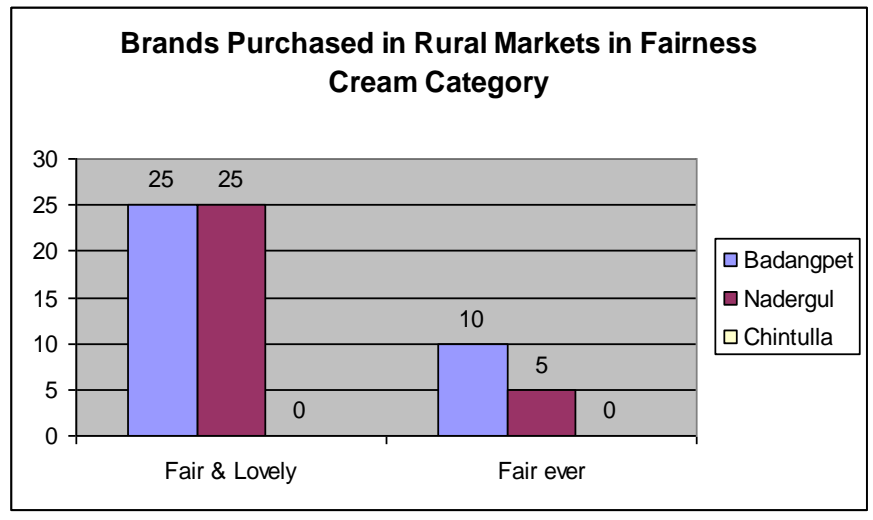

It is very clear, from the above table and graph that the Fair \& Lovely brand dominates the Badangpet and Nadergul in Fairness Cream Category and Chintula market left untapped as the consumption pattern is very low or no consumption.

\section{Reasons for Purchase of Brands in Badangpet Village}

Table 21: Attributes which made consumer to buy the brands of different products.

\begin{tabular}{|l|l|l|l|l|l|}
\hline Products & Quality & Price & Availability & Fragrance & others \\
\hline Soap & 15 & 2 & 0 & 20 & 3 \\
\hline Hair Oil & 2 & 25 & 0 & 10 & 5 \\
\hline Biscuits & 25 & 5 & 0 & 0 & 0 \\
\hline Tea & 15 & 0 & 0 & 0 & 30 \\
\hline Coffee & 0 & 0 & 0 & 0 & 0 \\
\hline Washing Powder & 20 & 5 & 0 & 15 & 0 \\
\hline Washing Soap & 25 & 10 & 0 & 20 & 0 \\
\hline Face Podwer & 0 & 10 & 0 & 30 & 0 \\
\hline Cold Cream & 0 & 0 & 0 & 10 & 30 \\
\hline Fairness Cream & 0 & 0 & 0 & 5 & 30 \\
\hline
\end{tabular}

\section{Graph 21:}

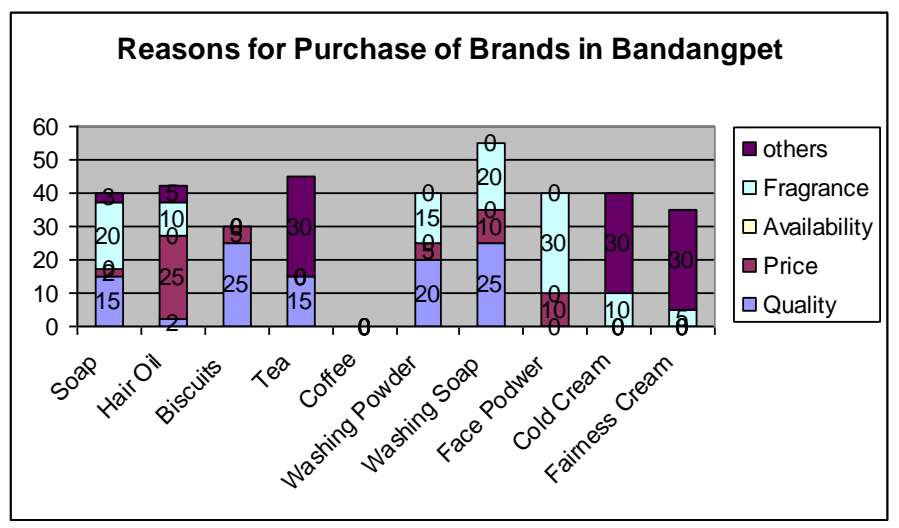

It is very clear, from the above table and graph that the consumers prefer the Quality or Price or fragrance based the product and its usag

\section{Reasons for Purchase of Brands in Nadergul Village}


The Importance of Brand in Consumer Buying Behavior of FMCG goods in Rural Markets

Table 22: Attributes which made consumer to buy the brands of different products.

\begin{tabular}{|l|l|l|l|l|l|}
\hline Products & Quality & Price & Availability & Fragrance & Others \\
\hline Soap & 0 & 5 & 0 & 20 & 0 \\
\hline Hair Oil & 0 & 20 & 10 & 0 & 0 \\
\hline Biscuits & 0 & 1 & 5 & 0 & 20 \\
\hline Tea & 0 & 10 & 10 & 30 & 10 \\
\hline Coffee & 0 & 0 & 0 & 0 & 0 \\
\hline Washing Powder & 0 & 5 & 0 & 15 & 0 \\
\hline Washing Soap & 0 & 30 & 5 & 10 & 4 \\
\hline Face Powder & 0 & 10 & 0 & 30 & 10 \\
\hline Cold Cream & 0 & 0 & 0 & 0 & 0 \\
\hline Fairness Cream & 0 & 5 & 0 & 0 & 15 \\
\hline
\end{tabular}

Graph 22:

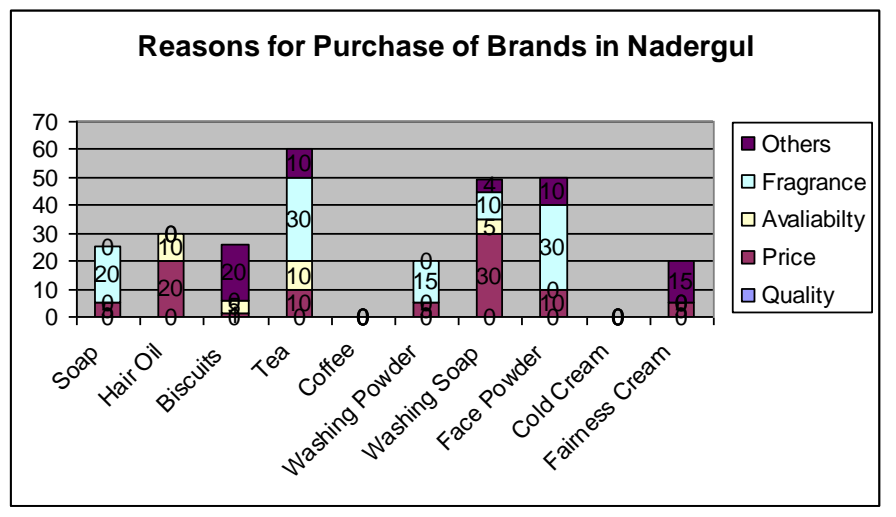

It is very clear, from the above table and graph that the nadergul market is price sensitive market and also few prefer fragrance of the brand.

\section{Reasons for Purchase of Brands in Chintulla Village}

Table 23: Attributes which made consumer to buy the brands of different products.

\begin{tabular}{|l|l|l|l|l|l|}
\hline Products & Quality & Price & Availability & Fragrance & Other \\
\hline Soap & 0 & 10 & 0 & 30 & 0 \\
\hline Hair Oil & 0 & 0 & 0 & 0 & 0 \\
\hline Biscuits & 0 & 0 & 0 & 0 & 0 \\
\hline Tea & 0 & 0 & 0 & 10 & 20 \\
\hline Coffee & 0 & 0 & 20 & 0 & 0 \\
\hline Washing Powder & 0 & 30 & 0 & 0 & 0 \\
\hline Washing Soap & 0 & 0 & 0 & 10 & 10 \\
\hline Face Powder & 0 & 0 & 10 & 0 & 20 \\
\hline Cold Cream & 0 & 0 & 0 & 0 & 0 \\
\hline Fairness Cream & 0 & 0 & 0 & 0 & 0 \\
\hline
\end{tabular}

\section{Graph 23:}

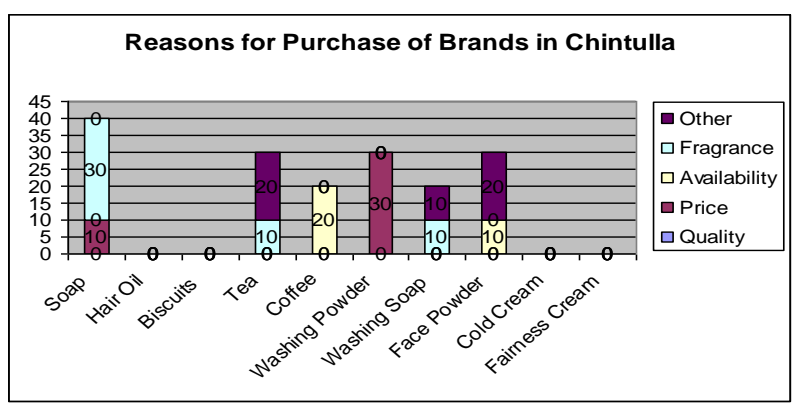


It is very clear, from the above table and graph that the Chintulla village is a Price sensitive market and availability of a product in the market also place major role.

Brand Loyalty of consumers in Rural Markets:

Table 24:

\begin{tabular}{|l|l|l|l|}
\hline Brand Loyalty & Badangpet & Nadergul & Chintula \\
\hline Always & 5 & 15 & 0 \\
\hline Mostly & 20 & 8 & 5 \\
\hline Sometimes & 5 & 3 & 5 \\
\hline Rarely & 0 & 4 & 20 \\
\hline
\end{tabular}

\section{Graph 24:}

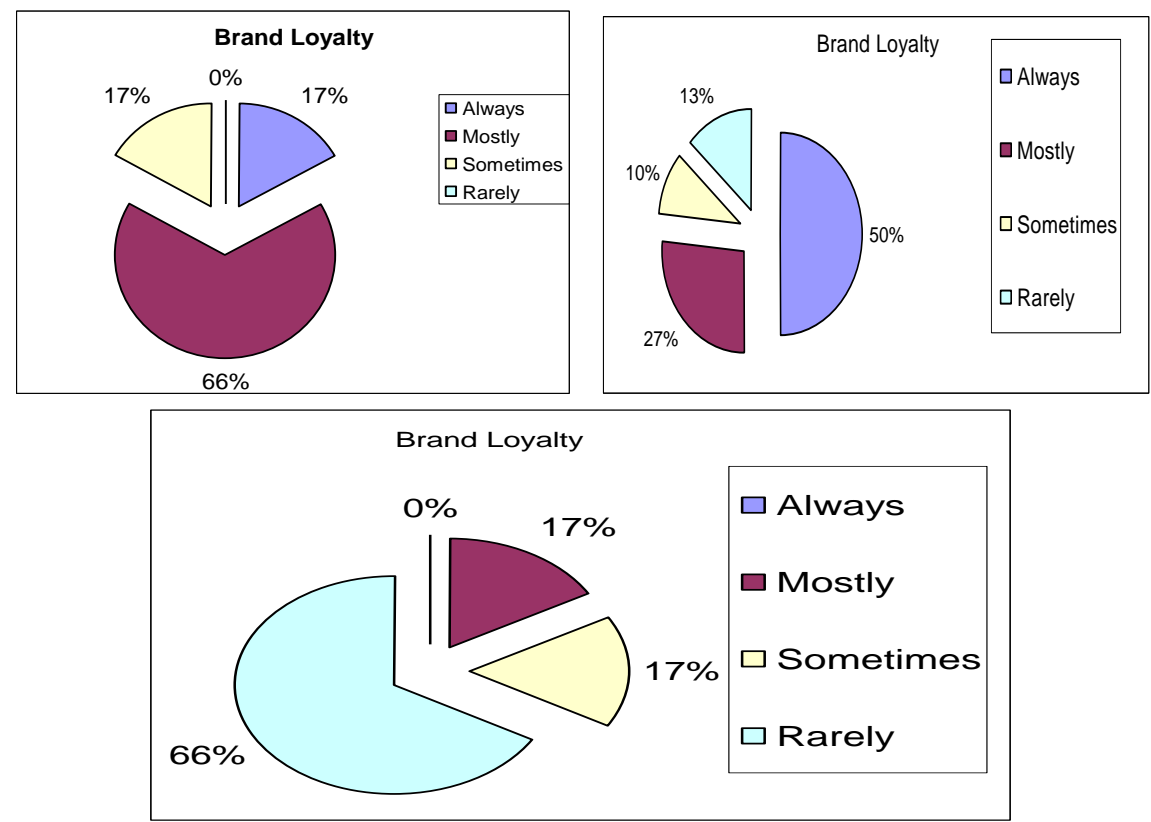

It is very clear, from the above table and Pie Chart that in all the three-selected sample rural markets brand loyalty is 1

\subsection{Data Analysis:}

Based on the colleted date in three sample villages, product wise brand awareness, purchase and loyalty are given in the table.

Soaps: In Soap category, awareness will match with purchasing behaviour and brand loyalty is more in Badangpet and Nadergul region and less in Chintulla.

Hair Oil: In Hair Oil category, branded products usage is more in Badangpet and Nadergul. Consumers prefer to buy local brands in Chintulla. Vatika and Navratan dominate in Badangpet, Parachute in Nadergul and Gograda local brand and Dabur in chintulla.

Biscuits: Biscuits consumption is less. In Biscuits category consumers mostly buy in loose those are available in near by shops like salt biscuits, Osmania biscuits etc. Parle-g and Tiger are mostly used brands in Badangpet.

Tea: Tea is purchased in loose, which is available in the local shops. The Popular brands Red Label, Three Roses and Gemini are used in Badangpet.

Coffee: Coffee Consumption is very less or no consumption in Nadergul and Chintulla. In Badangpet we could able to found few consumers and they consume BRU instant Coffee and also café or hotel we could able to find Instant powder and not filter coffee.

Washing Powder: In washing powder category, Nirma dominate all the three selected sample rural markets regions. In Remote area like Chintulla Nirma sell Rs.1 Sachets.

Washing Soap: In washing soap category Rin, 501, Nirma, XXX and Extra Local Brand dominates all the three selected rural markets.

Face Powder: In Face Powder category Pond's, Chintol, and Santoor dominates the market and it also need to see in other angle that consumption level is least.

Cold Cream: In Cold Cream Category Pond's has dominated the market in consumption in Badangpet. Less consumption in Nadergul and very less or no consumption in chintulla village. 
The Importance of Brand in Consumer Buying Behavior of FMCG goods in Rural Markets

Fairness Cream: Fairness Cream consumption is high in Nadergul and Badangpet. Fair and Lovely dominates the market and very less or no consumption in chintulla village.

\subsection{Problems in Rural Marketing:}

1. People in villages are subject to traditions, habits, preferences and socio-cultural pressures.

2. Rural markets are price sensitive. Rural consumers are price conscious and they purchase simple and low priced goods.

3. Brand loyalty is very low in rural areas.

4. Communication problems with regard to the marketing information to the rural consumer because of low literacy.

5. Rural consumers are not exposed to organized advertising.

6. It is difficult to manage and organizing an effective distribution channel is another hurdle in rural marketing.

7. IMC in rural markets is difficult and makes incur high promotional costs.

8. Business concerns hesitate to enter to rural markets based the all the above problems and focus the business towards Urban and Semi-Urban markets.

\section{Suggestions and Conclusion:}

As per the analysis and information carried out the following suggestions and conclusions are arrived at:-

1) In the study majority of the respondents are male categories.

2) Male members of the family are alone going to buy consumer products.

3) Women are not interested in shopping and do not come out from their houses frequently.

4) Most of the families come under the agriculture category.

5) Family income is very low.

6) Product planning is very important to marketer to enter into rural market.

7) Non-Availability of brands is another reason which affects purchasing decision.

8) Packaging should be strong enough to stand rough handling because of poor infrastructure facilities and pack should be small.

9) Brand names should be simple, small and easy to remember and pronounce

10) Effective IMC is required to reach remote villages.

\section{Journals:}

\section{References}

[1.] A.M. Sakkthivel, Dr. Bishnupriya Mishra, Effectiveness of Sachets in Modifying Rural Consumers' Buying Behavior and Their Consumption Pattern- A Researcher's View, Indian Journal of Marketing, Volume XXXV • Number $2 \bullet$ February 2005

[2.] Dr.A.Selvaraj Rural Consumers' Behaviour Regarding Non Durable Goods: A Study In Erode District of Tamil Nadu, Indian Journal of Marketing, Volume XXXVII • Number $12 \cdot$ December 2007

[3.] Bamzai, Sandeep, 'Markets now target Bharat', Business India, September 6-17, 1999

[4.] Dr.C.Anandan, M.Prasanna Mohan Raj, A Study on Brand Preferences of Washing Soaps in Rural Areas, Indian Journal of Marketing, Volume XXXVII • Number $3 \cdot$ March 2007

[5.] Deepti Srivastava, MARKETING TO RURAL INDIA: A CHANGING PARADIGM, APJRBM Volume 1, Issue 3 (December, 2010)

[6.] Gosh, Aparisim, 'The New Rules of Rural Marketing', Business World, April, 1994

[7.] Dr. G. GANESAN, Dr. K. CHANDRA SEKAR RAO, Pondicherry Rural Tourism Marketing - A Strategy for Global-Local Linkage, Indian Journal of Marketing, Volume XXXV • Number $3 \cdot$ March 2005

[8.] Kala Vijayraghavan and Anamika Rath, 'FMCGs find rural treasure hunt tough', The Economic Times, December 15, 2000

[9.] Keshav Sharma, Deepak R. Gupta, Parikshat Singh Manhas, RURAL MARKETING CHALLENGES IN THE NEW MILLENNIUM A CASE STUDY, Delhi Business Review, Vol. 4, No. 1, January - June 2003

[10.] Dr.K.Maruthamuthu,K.Krishnakumar, M.Vasan, Consumer Behaviour and Brand Preference of Britannia Biscuits - An empirical study with reference to Salem, Tamil Nadu, Indian Journal of Marketing, Volume XXXVI • Number 8 • August 2006

[11.] Dr. K. Ramasamy, Dr. G. Kalaivanan, S. Sukumar, Consumer Behaviour Towards Instant Food Products, Indian Journal of Marketing, Volume XXXV• Number $6 \cdot$ June 2005

[12.] Nithila Vincent, A Study on Brand Consciousness Among Children and its Effect on Family Buying Behaviour in Bangalore City, Indian Journal of Marketing, Volume XXXVI • Number 1・ January 2006

[13.] Dr.Pawan Garga, Dr.Kaminder Ghuman, Dr.Balram Dogra Rural Marketing of Select Fast Moving Consumer Goods in Punjab, Indian Journal of Marketing, Volume XXXIX • Number 5 • May 2009

[14.] Mr.Rajesh Shinde, Recent Facets of Consumer Behaviour: A Case of Rural Market, Indian Journal of Marketing, Volume XXXVII - Number 4 • April 2007

[15.] Dr. R. K. Srivastava, Ankur Singhal, Pasupula Raghavi, Mudit Khandelwal, Srikrishnan Balasubramanian, Swapnil Shirodkar, Brands Equity of Toothpaste Brands in India, Indian Journal of Marketing, Volume XXXV • Number $7 \bullet$ July 2005

[16.] S.Arul Kumar, Dr.C.Madhavi, Rural Marketing for -FMCG, Indian Journal of Marketing, Volume XXXVI • Number $4 \cdot$ April 2006 Website:

[17.] http://www.rediff.com/money/2003/oct/25spec $2 . \mathrm{htm}$

[18.] http://www.thehindubusinessline.com/features/brandline/article2224287.ece

[19.] http://hindu.com/2006/04/02/stories/2006040201911300.htm 